\title{
STUDI PENGARUH pH AWAL MEDIA DAN KONSENTRASI SUBSTRAT PADA PROSES FERMENTASI PRODUKSI BIOETANOL DARI HIDROLISAT TEPUNG BIJI KLUWIH (Actinocarpus communis) DENGAN MENGGUNAKAN Saccharomyces cerevisiae
}

\author{
I Gede Yogi Wikrama Yudaㄹ, I Made Mahaputra Wijaya², Ni Putu Suwariani² \\ ${ }^{1}$ Mahasiswa Jurusan Teknologi Industri Pertanian, Fakultas Teknologi Pertanian Unud \\ ${ }^{2}$ Dosen Teknologi Industri Pertanian, Fakultas Teknologi Pertanian Unud \\ Kampus Bukit Jimbaran, Badung, Bali \\ E-mail: yogiwikrama0@ gmail.com ${ }^{1}$ \\ E-mail koresponden: mahaputrawijaya@unud.ac.id ${ }^{2}$
}

\begin{abstract}
The aims of this study were to determine the optimum $\mathrm{pH}$ of media and substrate concentration on fermentation process that affected the production of bioetanol from kluwih (Actinocarpus communis) seed by Saccharomyces cerevisiae, and to obtain initial $\mathrm{pH}$ of media and substrate concentration on fermentation process that can a obtain the highest concentration of bioethanol. The research was designed by 2 factors. The first factor is initial $\mathrm{pH}$ of media that consist of three levels: 4, 4.5, and 5. The second factor is substrate concentration that consist of three levels: $2.5 \%, 5 \%$, and $7.5 \%$. The data was obtained from series of tests and then it analyzed and produced presented by descriptive method. The results showed that the initial $\mathrm{pH}$ of media had an effect on ethanol content, and the $\mathrm{pH}$, but not effected on total resulting suspended solid. Substrate concentration had an effect on ethanol content and total suspended solid. Interaction of both treatments had an effect on ethanol content from fermented flour of kluwih seed by used Saccharomyces cerevisiae. The best treatment to produce ethanol from fermented flour of kluwih seed is by using the initial $\mathrm{pH}$ of media 4.5 and substrate concentration amount $7.5 \%$ that yielded the highest ethanol content of $6.13 \mathrm{~mL}$.
\end{abstract}

Key words: Actinocarpus communis, ethanol, fermentation, the initial pH of media, substrate concentration

\section{PENDAHULUAN}

Bioetanol merupakan etanol hasil fermentasi gula, pati-patian atau biomassa lignoselulosa. Bahan dasar pembuatan bioetanol dari produk pati yang dapat digunakan antara lain; ubi kayu, ubi jalar, jagung dan sagu (Nurdyastuti, 2006). Bioetanol memiliki beberapa kelebihan dibandingkan energi alternatif lainnya, antara lain memiliki kandungan oksigen yang tinggi sehingga terbakar lebih sempurna, bernilai oktan lebih tinggi, dan ramah lingkungan (Handayani, 2007). Bioetanol adalah sumber energi terbarukan yang sangat berpotensi untuk dikembangkan di Indonesia, karena Indonesia merupakan negara yang memiliki sumber daya alam yang melimpah, disamping itu sebagian besar penduduk (masyarakat) bekerja pada sektor pertanian (Nurdyastuti, 2006).

Indonesia kaya akan sumber daya alam hayati yang belum dimanfaatkan secara optimal. Salah satunya adalah kluwih (Actinocarpus communis) atau disebut buah timbul. Kluwih merupakan salah satu tanaman yang banyak ditemukan di Indonesia. Buah kluwih mirip sukun, bedanya kluwih berkulit kasar dan memiliki biji, sementara sukun berkulit lebih halus dan tidak berbiji (Novary, 1999). Biji kluwih yang sudah tua dijual dalam bentuk matang yaitu direbus, makanan ini banyak ditemui di daerah pedesaan tetapi memiliki nilai ekonomis yang rendah. Mengacu pada penelitian Agustina (2005) kandungan pati biji kluwih berkisar antara 30,15-39,09\%. Biji kluwih juga mengandung lemak sebesar 5,59\%, serat sebesar $8,19 \%$, abu sebesar $1,49 \%$, fenol sebesar $0,06 \%$ dan karbohidrat sebesar $64,96 \%$. Kandungan gizi 
yang cukup tinggi pada biji kluwih ini belum diketahui luas oleh masyarakat sehingga pemanfaatan biji kluwih masih sangat terbatas. Melihat kenyataan bahwa potensi ekonomis biji kluwih belum banyak dimanfaatkan, maka untuk lebih meningkatkan pemanfaatan biji kluwih digunakan sebagai alternatif bahan pembuatan pembuatan bioetanol.

Proses pembuatan bioetanol dari bahan berkarbohidrat, membutuhkan proses hidrolisis yang bertujuan untuk memecah pati menjadi monosakarida (glukosa dan xylosa) yang selanjutnya akan difermentasi menjadi etanol. Proses hidrolisis dapat dilakukan secara kimiawi dan enzimatis. Metode hidrolisis yang banyak digunakan adalah hidrolisis asam dan basa karena lebih mudah prosesnya serta memerlukan biaya yang lebih rendah dibandingkan hidrolisis enzimatis (Setyawati et al, 2011). Saat ini metode hidrolisis asam masih lebih banyak diterapkan baik dalam penelitian maupun industri dibanding dengan hidrolisis enzimatik .

Fermentasi pada produksi bioetanol dimaksudkan untuk mengubah glukosa menjadi etanol (alkohol) dengan menggunakan yeast atau khamir. Jenis khamir yang biasanya digunakan adalah Saccharomyces cerevisiae. Khamir jenis ini merupakan spesies khamir yang memiliki daya konversi gula menjadi etanol tinggi (Sassner, 2008). Saccharomyces cerevisiae memerlukan suhu fermentasi sekitar 30 ${ }^{\circ} \mathrm{C}$ (Sassner, 2008). Proses fermentasi dipengaruhi oleh berbagai faktor yang harus dikontrol agar proses berlangsung optimal, antara lain suhu, $\mathrm{pH}$, oksigen, dan substrat (Subekti, 2006). Dalam proses fermentasi, $\mathrm{pH}$ merupakan variabel pertumbuhan mikroorganisme yang sangat penting, karena mikroorganisme hanya dapat tumbuh pada kisaran $\mathrm{pH}$ tertentu. Untuk Saccharomyces cerevisiae, pertumbuhan yang optimal berlangsung dalam media dengan $\mathrm{pH} 4,0-5,0$. Pada $\mathrm{pH}$ di bawah 3, proses fermentasi alkohol akan berkurang kecepatanya (Buckle et al., 2007). selain itu, mikroorganisme juga memerlukan substrat yang mengandung nutrisi sesuai dengan kebutuhan yang diperlukan untuk pertumbuhannya (Subekti, 2006). Berdasarkan hal tersebut di atas maka akan dilakukan penelitian mengenai proses fermentasi produksi bietanol dari biji kluwih dengan menggunakan Saccharomyces cerevisiae dengan variabel $\mathrm{pH}$ awal media dan konsentrasi substrat.

\section{METODE PENELITIAN}

\section{Tempat dan Waktu}

Penelitian ini dilakukan di Laboratorium Bioindustri dan Lingkungan, Laboratorium Analisis Pangan, dan Laboratorium Mikrobiologi Pangan pada Fakultas Teknologi Pertanian, Universitas Udayana. Penelitian ini dilakukan selama 3 bulan yaitu dari Juli sampai dengan Oktober 2017.

\section{Bahan dan Alat}

Bahan utama pada penelitian ini adalah biji kluwih matang yang berwarna kecoklatan yang didapatkan dari desa Bungaya Kangin, Kecamatan Bebandem, Karangasem, Bali. Khamir yang dipergunakan Saccharomyces cerevisiae JCM7255 yang didapatkan dari Universitas Gajah Mada. Sementara bahan-bahan untuk propagasi mikroorganisme meliputi ekstrak yeast, pepton, dan bahan kimia yang digunakan adalah $\mathrm{NaOH}, \mathrm{HCL}, \mathrm{H}_{2} \mathrm{SO}_{4}$, indikator PP, $\mathrm{NaCl}$ (Merck), alkohol 70\% (Brataco chemika), aquades, buffer $\mathrm{pH} 4$ dan buffer $\mathrm{pH} 7$. 
Peralatan yang digunakan diantaranya: destilator dua tingkat, Laminar Air Flow (Biowizard), pH meter (Ditech), autoclave (Hirayama), spektrofotometer (Genesys 10S UV-VIS), sentrifuse (Centurion Scientific), hand refraktometer, wadah fermentasi berupa botol kaca kapasitas 1 liter, blender (Miyako), alkohol meter, timbangan analitik (Shimadzu), water bath (Thermology), labu ukur (Iwaki), shaker rotator (health H-MSR), Bunsen, tube, kuvet, , magnetic stirer, pipet volume, pipet micro (Socorex), tabung reaksi (Iwaki), erlenmeyer (Iwaki), Inkubator (Memmert).

\section{Rancangan Percobaan}

Penelitian yang dilakukan merupakan penelitian eksperimen dalam skala Lab dengan perlakuan yang dirancang dengan 2 faktor. Faktor I yaitu $\mathrm{pH}$ awal proses fermentasi $(\mathrm{P})$ yang terdiri dari 3 taraf yaitu $\mathrm{P} 1(\mathrm{pH}=4), \mathrm{P} 2(\mathrm{pH}=4,5), \mathrm{P} 3(\mathrm{pH}=5)$. Faktor II adalah Konsentrasi substrat (S) yang terdiri dari 3 taraf yaitu : S1 (2,5\%), S2 (5\%), S3 (7,5\%). Dengan demikian diperoleh 9 kombinasi perlakuan. Masing-masing kombinasi perlakuan akan dilakukan pengulangan sebanyak 3 kali, sehingga keseluruhan ada 27 unit percobaan. Data yang diperoleh dari serangkaian pengujian kemudian dianalisis dan dipaparkan secara deskriptif. Data kemudian ditampilkan dalam bentuk grafik, tabel, gambar, maupun foto.

\section{Pelaksanaan Penelitian}

\section{Pembuatan Tepung Biji Kluwih}

Tahapan-tahapan yang dilakukan untuk pembuatan tepung biji kluwih meliputi: pengupasan, pengirisan, pengeringan pada suhu $50{ }^{\circ} \mathrm{C}$, penggilingan, pengayakan menggunakan ayakan 80 mesh (Sukatiningsih, 2005). Pengupasan bertujuan untuk menghilangkan kulit luar dan kulit ari pada biji kluwih. Pengirisan menggunakan pisau atau alat pengiris bertujuan untuk mempermudah dalam proses penepungan. Pengeringan biji kluwih dilakukan dengan dioven pada suhu $50{ }^{\circ} \mathrm{C}$ selama 10 jam, sehingga diperoleh biji kluwih yang sudah kering. Pengovenan selama 10 jam seharusnya sudah mengurangi kadar air menjadi minimal $14 \%$. Tahap selanjutnya dilakukan penepungan dan pengayakan, proses penepungan, yaitu dilakukan penggilingan atau pemblenderan biji kluwih yang sudah kering hingga halus, setelah itu dilakukan proses pengayakan dengan ayakan 80 mesh.

\section{Penghilangan Lemak (Defatting) Pada Tepung Biji Kluwih}

Metode maserasi dengan pelarut $n$-heksana digunakan untuk penghilangan lemak (defatting) tepung biji kluwih. Tahap awal metode maserasi yaitu tepung biji kluwih ditimbang sebanyak 100 gram kemudian direndam menggunakan pelarut $n$-heksana $300 \mathrm{~mL}$. Setelah itu diaduk menggunakan magnetic strirrer selama 15 menit, selanjutnya didiamkan selama 24 jam. Setelah itu dilakukan penyaringan untuk memisahkan pelarut $n$-heksana dan tepung biji kluwih, pelarut kemudian diamati warnanya bila masih belum bening, maserasi kembali diulangi hingga warna pelarut menjadi bening. Tepung biji kluwih yang sudah dihilangkan lemaknya diangin-anginkan untuk menguapkan $n$-heksana dan dikeringkan menggunakan oven pada suhu $50{ }^{0} \mathrm{C}$, Selanjutnya tepung biji kluwih diayak agar tepung tidak menggumpal. Tepung biji kluwih disimpan pada suhu $8{ }^{\circ} \mathrm{C}$ sebelum digunakan untuk penelitian (produksi bietanol). 


\section{Fermentasi Tepung Biji Kluwih}

\section{- $\quad$ Pembuatan Inokulum Saccharomyces cerevisiae JCM7255}

1. Peremajaan Isolat Saccharomyces cerevisiae JCM7255

Isolat Saccharomyces cerevisiae yang terdapat dalam botol disegarkan dengan cara diambil $1 \mathrm{~mL}$ kemudian dinokulasikan dalam media Glucose Yeast Pepton (GYP) $10 \mathrm{~mL}$ dalam tabung reaksi dan diinkubasi selama 24 jam pada suhu $28{ }^{\circ} \mathrm{C}$. Pertumbuhan positif dari isolat ini ditandai dengan perubahan kondisi media yang menjadi lebih keruh dan adanya endapan didasar tabung.

2. Perbanyakan isolat Saccharomyces cerevisiae JCM7255

Isolat yeast Saccharomyces cerevisiae ditumbuhkan pada media $200 \mathrm{~mL}$ media yang terdiri dari glukosa $1 \%(\mathrm{~b} / \mathrm{v}=2 \mathrm{~g})$, yeast ekstrak $0,5 \%(b / v=1 \mathrm{~g})$, dan pepton $0,5 \%(b / v=1 \mathrm{~g})$ yang telah dilarutkan dengan aquades dan disterilisasi di autoclave. Kemudian ditambahkan dengan starter Saccharomyces cerevisiae sebanyak $10 \%(v / v)$. Kemudian diinkubasi dengan suhu $28{ }^{\circ} \mathrm{C}$ selama 48 jam.

\section{- $\quad$ Hidrolisis Tepung Biji Kluwih (Rahayu et al,. 2010)}

Pada penelitian ini proses hidrolisis dilakukan secara kimiawi dengan pembuatan hidrolisat cair yaitu menambahkan asam sulfat $\left(\mathrm{H}_{2} \mathrm{SO}_{4}\right) 5 \mathrm{~N}$ ke dalam campuran tepung biji kluwih $100 \mathrm{~g}$ dan aquades $500 \mathrm{~mL}$ sampai mencapai $\mathrm{pH}$ 2,5. Setelah itu dilakukan pemanasan dengan menggunakan autoclave dengan suhu $121{ }^{\circ} \mathrm{C}$ selama 30 menit. Hasil hidrolisat kemudian diamati tingkat kesempurnaan proses hidrolisis berdasarkan warna hidrolisat yang merata dan tidak adanya gumpalan tepung biji kluwih.

\section{- $\quad$ Persiapan Media Fermentasi}

Tambahkan pepton $5 \mathrm{~g} / \mathrm{L}$, yeast ekstrak $5 \mathrm{~g} / \mathrm{L}$ sebagai nutrisi mikroorganisme ke dalam botol fermentasi, lalu ditambahkan aquades ke dalam botol fermentasi. Selanjutnya media disterilisasi pada suhu $121{ }^{\circ} \mathrm{C}$ selama 15 menit didalam autoclave. Kemudian hasil hidrolisat ditimbang hingga mencapai perlakuan konsentrasi substrat tepung biji kluwih 2,5\%, $5 \%$, 7,5 \%, dan dimasukan kedalam media fermentasi yang telah di sterilisasi hingga mencapai 1 liter, kemudian pHnya diatur sesuai dengan perlakuan ( $\mathrm{pH} 4,4,5,5)$.

\section{- $\quad$ Proses Fermentasi}

Selanjutnya media fermentasi diinokulasikan dengan inokulum Saccharomyces cerevisiae yang telah dibuat, ditambahkanan sebanyak $1 \%(10 \mathrm{~mL})$ dari volume total, kemudian dilakukan fermentasi selama 7 hari.

\section{- $\quad$ Proses Destilasi}

Hasil fermentasi kemudian didestilasi dengan menggunakan destilator dua tingkat, dimana suhu pada distilator tingkat kedua diatur $80-85{ }^{\circ} \mathrm{C}$. Destilasi dilakukan selama 3 jam. Diagram alir proses fermentasi tepung biji kluwih bisa dilihat pada Gambar 1. 


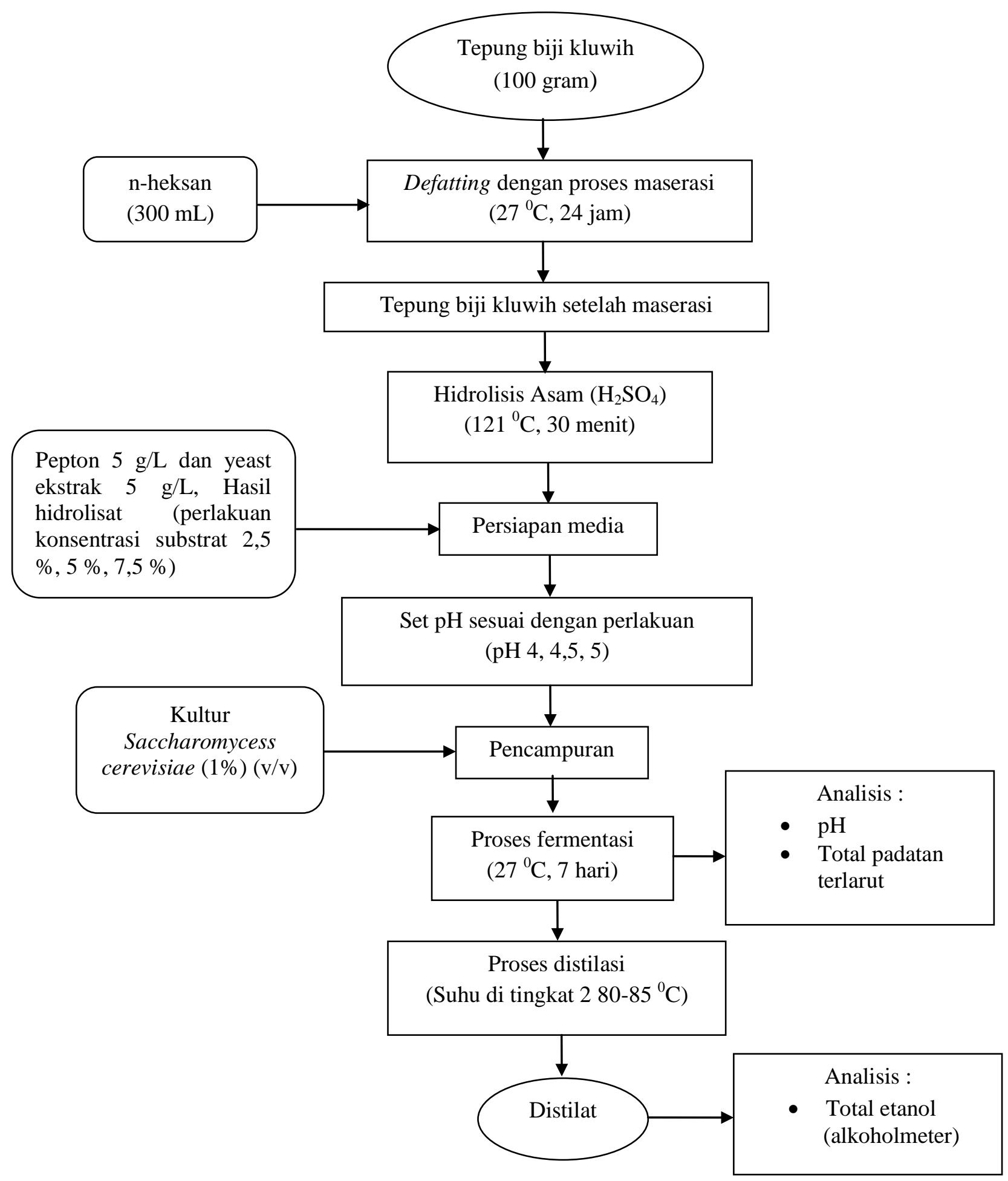

Gambar 1. Diagram alir proses fermentasi tepung biji kluwih 


\section{Variabel yang Diamati}

Variabel yang diamati yaitu analisis total etanol menggunakan alkoholmeter total padatan terlarut (Muchtadi, 1989), penentuan derajat keasaman (pH) (Sudarmadji et al., 1997).

\section{HASIL DAN PEMBAHASAN}

\section{Total Etanol (ml)}

\section{Total Etanol (mL)}

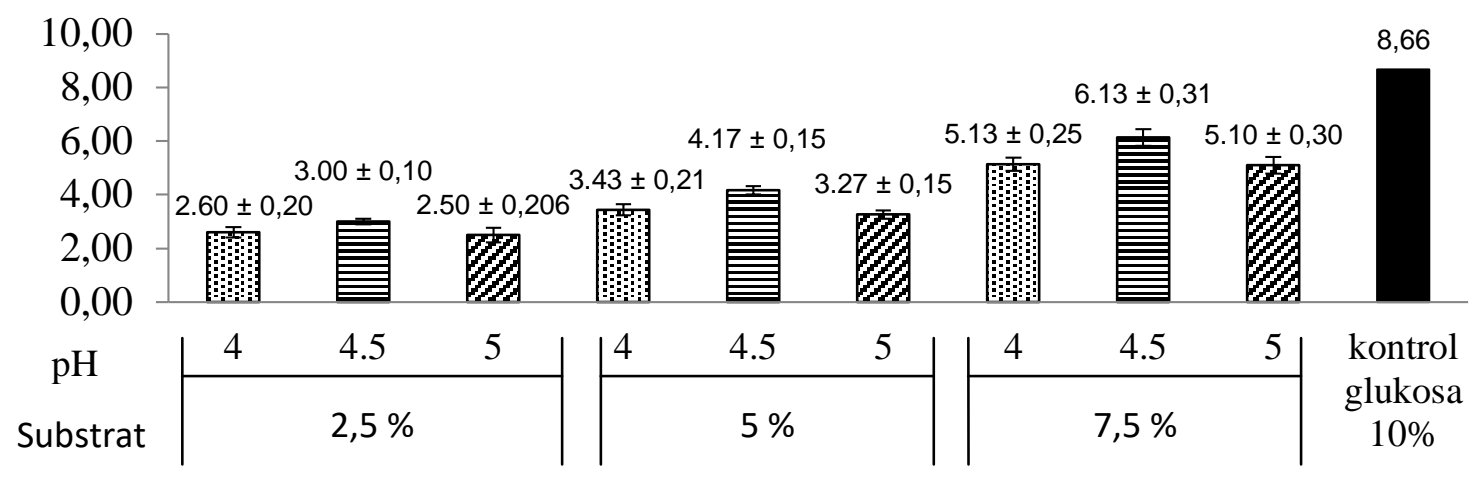

Gambar 2. Kadar Etanol Hasil Fermentasi Tepung Biji Kluwih

Berdasarkan hasil diatas pada Gambar 2 pada perlakuan $\mathrm{pH}$ 4, menunjukan baik pertumbuhan maupun aktivitas khamir belum maksimal memperoleh energi melalui pemecahan substrat atau katabolisme guna keperluan metabolisme dan pertumbuhan dibandingkan $\mathrm{pH}$ 4,5 (Astuti 1991). Katabolisme substrat oleh khamir dimulai dengan pemecahan glukosa yang terdapat dalam substrat bersangkutan. Pada tahap ini tidak terjadi perubahan potensial oksidasi-reduksi pada substrat dan pertukaran energi sangat kecil. Seperti yang dinyatakan Johnson (1970) bahwa untuk melangsungkan berbagai aktifitas tersebut diperlukan energi dalam jumlah besar. Khamir dalam kondisi $\mathrm{pH}$ yang optimal mampu mencerna sejumlah nutrien yang beratnya sama dengan beratnya sendiri dalam setiap beberapa detik untuk memenuhi jumlah energi yang dibutuhkan (Prescott et al.,1981).

Khamir mulai optimal mencerna nutrien pada perlakuan $\mathrm{pH}$ awal 4,5 dan konsentrasi substrat 7,5 $\%$ dan menghasilkan kadar etanol tertinggi sebesar $6,13 \mathrm{~mL}$. Hal ini dikarenakan bahwa seiring pertumbuhan Saccharomyces cereviseae, khamir mampu mensintesis energi dengan sempurna melalui aktivitas memecah glukosa, dan akhirnya mengeluarkan (eksresi) produk-produk metabolisme yang terbentuk berupa etanol, pada $\mathrm{pH}$ ini khamir memasuki fase pertumbuhan yang dipercepat. Ketika $\mathrm{pH}$ ditingkatkan, maka laju pertumbuhan akan menurun dan akhirnya pertumbuhan berhenti sama sekali. Berhentinya pertumbuhan dapat disebabkan karena berkurangnya beberapa nutrien esensial dalam medium, atau karena terjadinya akumulasi autotoksin dalam medium atau kombinasi dari keduanya. Produk etanol akan mulai turun sampai fermentasi mendekati $\mathrm{pH}$ 5. Derajat keasaman (pH) optimum untuk proses fermentasi yang sama dengan $\mathrm{pH}$ optimum untuk proses pertumbuhan khamir yaitu $\mathrm{pH} 4,0-$ 4,5 (Astuti 1991). Derajat Keasaman atau $\mathrm{pH}$ dari media sangat mempengaruhi pertumbuhan 
mikroorganisme. Setiap mikroorganisme mempunyai $\mathrm{pH}$ minimal, maksimal, dan optimal untuk pertumbuhannya. Untuk yeast, $\mathrm{pH}$ optimal untuk pertumbuhannya berkisar antara 4,0 sampai 4,5. Menurut Volk (1993) menyatakan bahwa pada pH dibawah 3 ternyata hasil fermentasi etanol akan semakin rendah, karena fermentasinya berjalan lambat. Jadi ada indikasi apabila $\mathrm{pH}$ dibawah 4, kadar etanol yang akan dihasilkan akan rendah.

Saccharomyces cereviseae tidak berkerja secara optimal pada $\mathrm{pH} 5$, dimana diperoleh kadar etanol yang lebih rendah dari 6,13 $\mathrm{mL}(\mathrm{pH}$ awal 4,5) menjadi 5,10 $\mathrm{mL}$ (pH awal 5). Fase ini mungkin disebabkan oleh kadar glukosa cenderung lebih rendah, dimana glukosa digunakan sebagai sumber karbon bagi sel khamir, sehingga khamir tidak dapat menguraikan untuk menjadi etanol dan sebagian khamir akan mati. Fase ini juga khamir menghasilkan produk samping, produk samping dari proses fermentasi berupa asam asetat yang mengalami reaksi lanjut serta larutan pati menjadi 3 lapisan yaitu lapisan bawah berupa endapan protein, air dan etanol (Volk, 1993).

Total etanol fermentasi tepung biji kluwih dengan konsentrasi substrat 2,5\%, 5\%, dan 7,5\% memiliki koefisien hasil etanol sebesar 0,12, 0,08 dan 0,08. Konsentrasi substrat 2,5\% memiliki koefisien etanol tertinggi daripada konsentrasi substrat lainnya. Menurut Prescott (1981) faktor yang mempengaruhi peningkatan kadar etanol selama proses fermentasi, adalah ketersediaan substrat yaitu gula reduksi dan jumlah mikrobia, yaitu S. cerevisiae. Meskipun total gula reduksi tertinggi didapat dari konsentrasi substrat 7,5\%, tetapi kondisi medium masih relatif padat, sehingga kurang dapat dimanfaatkan Saccharomyces cereviseae untuk menghasilkan etanol, selain itu terdapat bentuk lain hasil perubahan substrat. Bentuk lain itu adalah biomassa dan senyawa organik lainnya.

\section{Total Padatan Terlarut (Brix)}

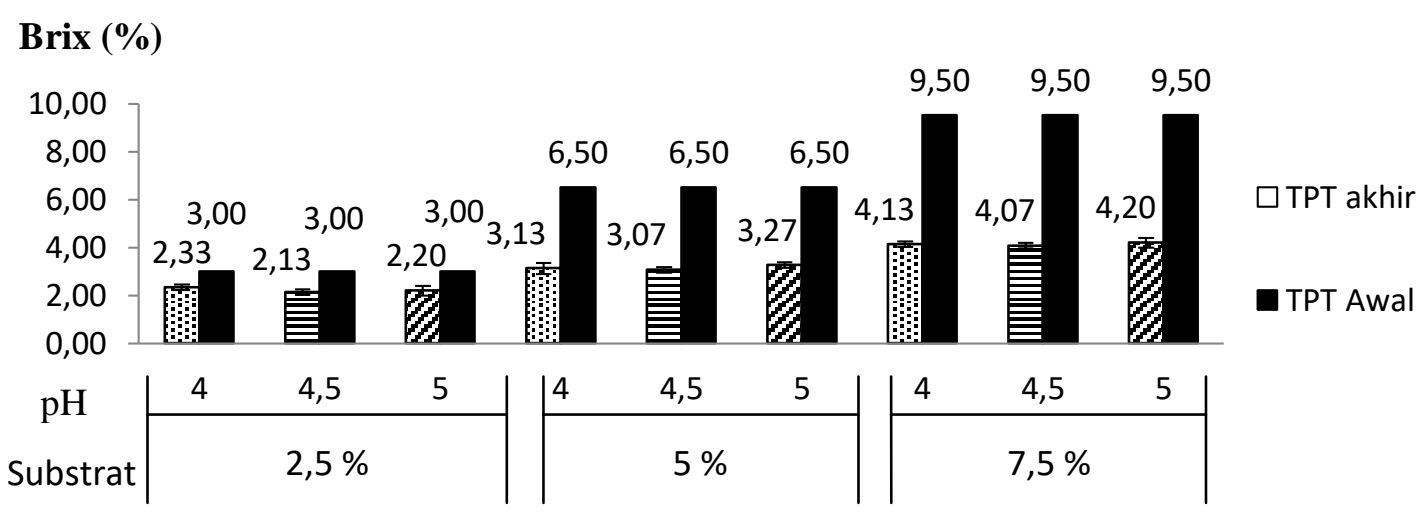

Gambar 3. Total Padatan Terlarut Hasil Fermentasi Tepung Biji Kluwih

Pada Gambar 3 dapat dilihat bahwa pada pH awal 4,5 total padatan terlarut akhirnya paling rendah dibandingkan dengan $\mathrm{pH}$ awal 4 dan 5 di semua konsentrasi substrat. Buckle et al., (1985) menyatakan bahwa $\mathrm{pH}$ optimal untuk pertumbuhan ragi adalah 4,5. Pada $\mathrm{pH}$ 4,5 khamir Saccharomyces cerevisiae akan maksimal dalam metabolisme. Selama proses fermentasi berlangsung, gula akan dimetabolisme oleh Saccharomyces cerevisiae menjadi alkohol dan $\mathrm{CO}_{2}$, sehingga total padatan terlarut menjadi rendah, seperti dikemukakan Sintasari (2014), bahwa rendahnya total padatan terlarut diduga karena selama proses fermentasi berlangsung, gula yang merupakan komponen padatan yang dominan 
dalam medium dimetabolisme oleh khamir menjadi alkohol dan $\mathrm{CO}_{2}$ kemudian dimanfaatkan oleh bakteri asam sebagai sumber karbon sehingga total padatan terlarut menjadi rendah. Hal ini diperkuat dengan pernyataan Sartika (2010), dimana penurunan total padatan terlarut selama penyimpanan disebabkan gula yang terkandung akan mengalami perubahan menjadi alkohol, aldehida dan asam amino. Sisa-sisa asam organik, sukrosa maupun laktosa yang terlarut dalam air yang akan terhitung sebagai total padatan terlarut (Sintasari,2014). Penurunan total padatan terlarut juga disebabkan oleh aktivitas khamir dalam memecahkan gula untuk menghasilkan alkohol selama proses fermentasi. Khamir membutuhkan substrat dan nutrien untuk keperluan hidupnya. Substrat dan nutrien akan berkurang, sehingga menyebabkan jumlah total padatan terlarut pada media menjadi berkurang (Fiecher,1982).

Pada $\mathrm{pH}$ awal 4,5 total padatan terlarut akhirnya paling rendah dengan total etanol paling tinggi, Menurut penelitian Reed et al., (1991), bahwa selama proses fermentasi khamir dan bakteri berlangsung, terjadi penurunan total padatan terlarut. Semakin rendah kadar total padatan terlarut maka semakin baik dan semakin tinggi etanol yang dihasilkan, sebaliknya semakin tinggi kadar total padatan maka etanol yang dihasilkan semakin keruh dan kurang baik.

\section{Derajat Keasaman (pH)}

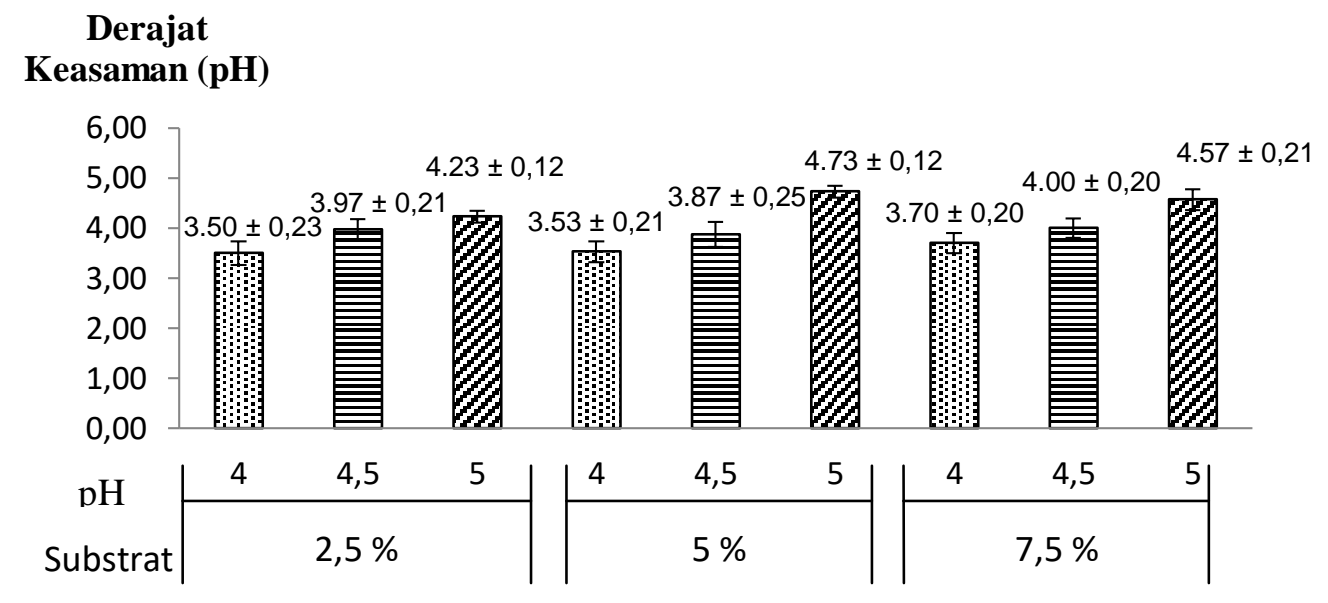

Gambar 4. Nilai pH Hasil Fermentasi Tepung Biji Kluwih

Gambar 4 diatas menunjukkan bahwa terjadinya penurunan derajat keasaman $(\mathrm{pH})$ pada cairan biji kluwih setelah proses fermentasi selama 7 hari. Seperti perlakuan $\mathrm{pH}$ awal fermentasi 4 setelah fermentasi 7 hari menjadi 3,50, dimana hal disebabkan semakin lama fermentasi maka pH media akan semakin menurun sesuai dengan penelitian Fadilah (2018). Hal ini disebabkan semakin lama fermentasi maka akan terbentuk produk fermentasi selain etanol sehingga dapat menurunkan $\mathrm{pH}$ media. Menurut Purwoko (2007) pada proses fermentasi tidak hanya dihasilkan etanol dan karbondioksida akan tetapi juga dihasilkan produk samping seperti gliserol dan asam asetat. Taherzadeh et al., (2007) menambahkan bahwa asam asetat dapat berdifusi melalui membrane sel dengan menurunkan $\mathrm{pH}$ internal. Dengan demikian ketika $\mathrm{pH}$ rendah (asam) maka aktifitas enzim akan terhambat sehingga kemampuan mikroba untuk mengurai gula menjadi bioetanol semakin rendah.

Derajat keasaman $(\mathrm{pH})$ merupakan salah satu dari beberapa faktor penting yang mempengaruhi fermentasi alkohol. Derajat keasaman $(\mathrm{pH})$ optimum untuk proses fermentasi adalah antara 4-5. Pada $\mathrm{pH}$ 
dibawah 3, proses fermentasi alkohol akan berkurang kecepatannya (Buckle et al., 2007). Hal tersebut di karenakan $\mathrm{pH}$ mempengaruhi efektivitas enzim yang dihasilkan mikroorganisme dalam membentuk kompleks enzim substrat.

\section{KESIMPULAN DAN SARAN}

\section{Kesimpulan}

Dari penelitian ini perlakuan $\mathrm{pH}$ awal media berpengaruh terhadap kadar etanol, dan $\mathrm{pH}$ akhir, tetapi tidak berpengaruh terhadap total padatan terlarut. Konsentrasi substrat berpengaruh terhadap kadar etanol, dan total padatan terlarut. Sedangkan interaksi kedua perlakuan berpengaruh terhadap kadar etanol hasil fermentasi tepung biji kluwih menggunakan Saccharomyces cerevisiae.Perlakuan terbaik untuk menghasilkan etanol dari fermentasi tepung biji kluwih adalah dengan $\mathrm{pH}$ awal media 4,5 dan konsentrasi substrat 7,5\%, yang menghasilkan total etanol tertinggi sebesar $6,13 \mathrm{~mL}$.

\section{Saran}

Penelitian lebih lanjut mengenai proses fermentasi tepung biji kluwih perlu dilakukan. Selain itu mempertimbangkan faktor lain sebagai perlakuan tambahan, misalnya faktor suhu atau penggunaan mikroba jenis lain serta dengan menambahkan rentang waktu fermentasi, untuk mengetahui perlakuan yang menghasilkan bioetanol dengan kadar etanol tertinggi.

\section{DAFTAR PUSTAKA}

Agustina, 2005. Pengaruh Blanching Natrium Klorida dan Natrium Metabisulfit Sifat Fisikokimia dan Fungsional Tepung Biji Kluwih (Artocarpus comminis G.Forst). Jur. THP, FTP. Univ.Jember.

Astuty, E. D. 1991. Fermentasi Etanol Kulit Buah Pisang. UGM. Yogyakarta.

Fiechter, A. 1982. Advances in Biochemical Engineering. Springer-Verlag, Berlin.

Handayani, 2007. Peningkatan Nilai Nutrisi Tepung Azolla Melalui Fermentasi. Laporan Penelitian. Lembaga penelitian UMM, Malang. $17 \mathrm{hlm}$.

Hepworth, M. 2005. Technical Enviromental and Economic aspects of Unit Operation for The Production of Bioethanol From Sugar Beet in the United Kingdom. CET IIA Exercise 5, corpus Christi College.

Novary, E.W. 1999. Penanganan dan Pengolahan Sayuran Segar, Penebar Swadaya, Jakarta

Nurdyastuti. 2006. Prospek Pengembangan Bio-fuel sebagai Substitusi Bahan Bakar Minyak: Teknologi Proses Produksi BioEthanol. http://xa.ying.com/kq/groups/346847/65805552/Bio_Ethanol.pdf.

Prescott and Dunn. 1981. Industrial Microbiology 4th Edition. AVI Publishing Company Inc., Westport conecticutt.

Rahayu, S.G. 2010. Pengaruh Perbandingan Berat Padatan dan Waktu Reaksi Terhadap Gula Preduksi Terbentuk Pada Hidrolisis Bonggol Pisang. Jurnal Teknik Kimia Indonesia. 9(3):77-82.

Reed, G. and T.W Nagodawithana. 1991. Yeast Technology Van Nostrand Reinhold Publisher. New York. 
Roukas, T. 1996, Continuous Ethanol Production fromNonsterilized Carob Pod Extract by Immobilized Saccharomyces cerevisiae on Mineral Kissiris Using A Two-reactor System. Journal Applied Biochemistry and Biotechnology, Vol. 59, No. 3.

Sartika, R. 2010. Pengaruh Suhu dan kelembaban Udara Terhadap Shelf-Life dan Karakteristik Buah Manggis (Garcinia mangostana L.) Selama Pemyimpanan. IPB, Bogor

Sassner. P, C.G. Martensson, M . Galbe, and G. Zacchi. 2008. Steam Pretreatment of $\mathrm{H}_{2} \mathrm{SO}_{4}$-Impergnated Salixfor Production of bioethanol. J. Bioresource technol. 99(2008) : 137-145.

Setyawati, H. dan Rahman N. A. 2011. Bioetanol dari Kulit Nanas dengan Variasi Massa Saccharomyces cereviceae dan Waktu Fermentasi. Berkala Ilmiah Teknik Kimia Vol. 1 (1). Institut Teknologi Nasional Malang, Malang.

Sintasari, R. A. 2014. Pengaruh Penambahan Konsentrasi Susu Krim dan Sukrosa Terhadap Karakteristik Minuman Probiotik Sari Beras Merah. Fakultas Teknologi Pangan, Malang.

Subekti H. 2006. Produksi etanol dari hidrolisat fraksi selulosa tongkol jagung. Tidak dipublikasikan. Fakultas Teknologi Pertanian, Institut Pertanian Bogor

Suryaningsih,W., 1993. Pengaruh Tingkat Penambahan Nangka muda dan Kluwih Dalam Pembuatan Dendeng Sapi Terhadap Mutu Produk,. Politehnik Pertanian Universitas Jember

Sun, Y., and Cheng, J., 2002. Hydrolysis of lignocellulosic materials for ethanol production: a review. Bioresource Technol. 83, 1-11.

Sudarmadji. S., Haryono. B., dan Suhardi. 1997. Prosedur Analisa untuk Bahan Makanan dan Pertanian. PAU Pangan dan Gizi Universitas Gaja Mada, Yogyakarta.

Taherzadeh, M. J. dan K. Karimi. 2007. Enzyme-Based Hydrolysis Processes For Ethanol From Lignocellulostic Materials . A Review. BioResources 2(4), hal: 707-738.

Volk, W.A., dan Wheeler, M.F., 1993. Mikrobiologi Dasar.Erlangga, Jakarta. 